\title{
Mutual influence between firms and tourist destination: a case in the Douro Valley
}

\author{
Ricardo Fontes Correia • Carlos Melo Brito
}

Received: 19 November 2013 / Accepted: 16 February 2014 /Published online: 6 March 2014

(C) Springer-Verlag Berlin Heidelberg 2014

\begin{abstract}
Firms and the territories where they are located are interwoven realities. The evolution of territories is influenced by the strategies adopted by the firms as well as these depend on the characteristics and dynamics of the region where they are embedded. The interconnection between firms and territories is thus a key issue for the understanding of the development of both businesses and territories. This issue is particularly important for the tourism industry inasmuch as the attractiveness of a region depends not only on the endogenous resources of the territory but also on the spatial interaction established by companies. In this context, the purpose of this paper is to clarify the reciprocal influence between firms and tourist destinations. For that, the paper analyses the case of a tourist resort established in the Douro valley, a region in northern Portugal classified by UNESCO as World Heritage Site and where Port wine is produced. On the basis of a qualitative methodological approach, the study aims at understanding (i) how firms' strategic actions influence the structure and dynamics of the region where they are located, and (ii) how the regional characteristics influence firms' evolution. The study shows that local actors are likely to condition the possibilities of interaction or ways to act in the market, develop new activities on the basis of innovative ways to combine their resources, connect with other actors of the focal firm's network and create new competences. On the other hand, the inability of local actors to interact with the focal firm can limit its strategic options and, consequently, the impact on the dynamics of the territory as a whole.
\end{abstract}

Keywords Tourism · Destination Marketing · Interaction · Relationships · Case Study · Douro Valley · Aquapura

R. F. Correia $(\bowtie)$

School of Public Management, Communication and Tourism, Polytechnic Institute of Bragança, PO Box 128, 5370-326 Mirandela, Portugal

e-mail: ricardocorreia@ipb.pt

C. M. Brito

Faculty of Economics, University of Porto, Rua Roberto Frias, 4200-464 Porto, Portugal

e-mail: cbrito@fep.up.pt 


\section{Introduction}

Thanks to the interactions they develop firms are one of the most important actors in any region. They generate regional characteristics through the way they train workers or insert knowledge into the region where they are located. In fact, many of their interactions create a proximity between different regional contexts (Dicken and Malmberg 2001; Baraldi, Hjalmar and Houltz 2006). The relations between firms and the regions where they act are clearly reciprocal (Baraldi 2006; Glückler 2007). This mutual influence is clearly stated in the article published by Schoenberger in 1999 "The Firm in the Region and the Region in the Firm" where the author relates the importance of the specificities and local stories which will inevitably produce effects on the firms' performance, providing them with specific features in this context. As such, there are two levels of interaction, the regional and the corporate level (Schoenberger 1999; Baraldi, Hjalmar and Houltz 2006).

This process of corporate influence is much more evident in tourism. Even organizations which do not consider themselves dependent on tourism will condition the region through their performance, since they obviously contribute to the social and economic dimension of a given tourist destination (McKercher 1993; Grängsjö 2003). In addition, tourism tends to develop in a confined regional area, where different business organizations need to coordinate efforts in order to boost it. This industry is often described as encompassing a large number of small firms producing complementary products but which are generally independent (Hjalager 2000).

At the same time, the tourist destination is taken to be the most relevant element in this industry because it is the destination that emanates attributes expected by consumers (Murphy, Pritchard and Smith 2000). This means that "the destination domain is thus characterized by an "open-system" of interdependent, multiple stakeholders, where the actions of one stakeholder impact on the rest of the actors in the community" (Jamal and Getz 1995: 193). The institutional context of such a destination as well as the proactivity of its administrative organisations is one of the most important influences on tourist firm management, particularly in smaller ones (Smeral 1998; Ateljevic and Doorne 2004). At a time when globalisation threatens many regional specificities, tourists are looking for connections and experiences which are rooted in the destination itself (Boyle 2004). Local factors, such as culture and the environment and the way they influence the development of tourism in a particular region, have gained importance in recent years (Shaw and Williams 2000; Milne and Ateljevic 2001). Despite the fact that relations and interactions established between firms and regions have gained the status of a study area over time, "such relationships need clearer articulation and understanding". So far, "little attention has been paid to the precise nature of that relationship", and therefore "the relationships between firms and territories are weakly conceptualized" (Dicken and Malmberg 2001: 346).

The objective of this research is twofold: (i) to explain how the strategic action of firms impacts the regional dynamics and structure and (ii) how the regional characteristics affect the firms' action. To pursue these objectives, the article is organized as follows. In Section 2 there is a literature review based on two important streams of research: relational geography and the interaction approach. In the following section we present the research questions and justify the design of the analysis model. In Section 4 we explain the adoption of a qualitative methodology based on a case study to guide the 
research. The analysis of the Aquapura case in the context of the Portuguese Douro Region is then presented. The article finishes with a set of conclusions, limitations and suggestions for further research.

\section{Theoretical background}

\subsection{Relational geography}

Relational and interactive elements have been introduced into the definition of territory, giving rise to what is known as "relational geography" (Storper 1997; Dicken et al. 2001; Dicken and Malmberg 2001; Bathelt and Glückler 2003; Boggs and Rantisi 2003; Ettlinger 2003; Amin 2004; Yeung 2005b; Bathelt 2006; Boschma and Martin 2010; Bathelt and Glückler 2011). Relational geography represents "a theoretical orientation where actors and the dynamic processes of change and development engendered by their relationships are central units of analysis" (Boggs and Rantisi 2003: 109). It is also a response to the traditional positions of economic geography, which are unable to explain micro dynamics, based on different kinds of social and economic coordination.

In fact, this relational perspective was developed as an alternative to regional approaches based on conventional economics. As Bathelt and Li (2014) state, since relational geography has introduced a social and institutional dimension, researchers have focused their attention not only on economic processes stricto sensu but also on social issues (Granger 2013) as well as on the way institutions are likely to influence the dynamics of territories (Bathelt and Glückler 2013).

In the relational approach three characteristics of economic action and interaction appear. They are regionally framed and invariably present (Bathelt and Glückler 2003; Bathelt 2006): (1) the importance of the context; (2) path-dependence; (3) contingency. These characteristics imply that "general spatial laws of economic action do not exist" (Bathelt 2006: 229) and as a result the generic regional development policies "cannot be developed like recipes which always work if all the ingredients are at hand" (Bathelt 2006: 230).

Within relational approaches a prominent role is given to firms because "it is the decision-making of firms, as private, profit-maximising agents, that shapes the territory and its development process" (Giuliani 2007: 143). Therefore, in order to understand the development flow and the regional dynamics it is necessary to place firms and their interactions at the centre of the analysis (Taylor and Asheim 2001; Bathelt and Glückler 2003; Martin and Sunley 2003; Yeung 2005a). At the same time firms "would encounter different local circumstances, population and histories that would remain distinctive" (Schoenberger 1999: 207) and which condition their performance.

The ability of the firm to identify, assimilate and explore the knowledge coming from its surroundings is called "absorptive capacity" by Cohen and Levinthal (1989). To assimilate and take advantage of any new information firms must have the ability to find, recognize and understand it. This may give rise to the development of new practices and activities. Recognising this requires a prior knowledge basis. Without this knowledge the available information may go unnoticed by regional actors. 


\subsection{The IMP interaction approach}

Although firms are considered to be a key regional actor, they are only superficially characterized by the relational approach. The lack of knowledge about the pillars of their strategic action is also remarkable. So, in order to respond to the research goal, it is necessary to combine the contributions of the relational approach with another theoretical perspective which allows the characterization of the corporate actors and the foundations of their strategic action.

The interaction approach fulfils this purpose. This approach has its genesis in the IMP Group (Industrial Marketing and Purchasing Group), which emerged in the 1980 s, and was initially focused on relations in the industrial markets, but it progressively generalized its analysis to relationships within services. Much of this approach results from the interaction model developed by Håkansson (1982) which is based on the assumption that the interested parties in the process of exchange are active, seeking to get value through interaction. The exchange process is understood as being versatile since the parties "are neither anonymous nor faceless, and where social interaction and technical adaptations are closely intertwined" (Håkansson and Waluszewski 2002: 28). The essence of the business does not only lie in what goes on inside the firms but more particularly in the interaction that takes place among them (Olsen et al. 2013).

\subsubsection{The interaction approach in the business context}

Interaction is interpreted as a process which changes and transforms aspects of the firms' activities and resources thus changing the characteristics of the firms involved. This process of interaction is one of the "major means through which companies systematically relate and combine their activities and resources with each other (Waluszewski et al. 2008: 3). Interaction is not a dyadic process. Firms interact simultaneously with several others and so any interaction between two firms may influence all the others. Due to their multiple connections, the relations assume a form which is conveniently illustrated by the network metaphor (Anderson et al. 1994; Koch et al. 2013).

In these positions there is a clear distance from the approaches which define the existence of boundaries between organizations and their surrounding context. Firms cannot build their strategy alone because it is the result of interactions and, as such, indexed to relationships (Ford and Håkansson 2006b; Roseira et al. 2013). In this way, interactions and relationships have asserted themselves as important or more important than the management itself to influence the firms' strategy.

In this perspective strategy refers to the "way in which a firm achieves exchange effectiveness in relation to other firms in the surrounding network - that is, how a firm initiates and reacts to changes in the network in such a way that the firm continues to be valuable to the network" (Holmen and Pedersen 2003: 409). The strategy is therefore the result of a joint process in which many firms participate (Ford and Håkansson 2006a). Consequently, much of the strategic performance implies influencing others, and managing relationships within an interaction context. In line with this position, Johanson and Mattsson (1992) argue that the foundations for the strategic action of a focal actor are its position, network theory and its resources. As a 
result, these elements combine features of the subjective and objective nature of the firms' strategic actions.

Within this perspective, Turnbull et al. (1996: 47) define position as "the company's relationships and the rights and obligations which go with them". The actors also form several cognitive structures which result from the interpretations of past relationships and experiences which have the ability to influence their actions in the future. These network theories, defined by Mattsson (2003: 417) as the 'actor's set of systematic beliefs about market structure, processes and performance and the effects of its own and others' strategic actions" not only affect the strategic performance of the actor that formulates them, but they can also may be transmitted to other actors, thus influencing their actions (Brito 2001).

\subsubsection{The interaction approach in the regional context}

The conceptual richness of the research within authors familiar with the IMP Group is currently so broad that it goes beyond the limits of industrial relations that were at the basis of their origin. In fact, among the authors identified with the IMP there are valuable contributions to the understanding of regional dynamics (Cova et al. 1996; Johnston and Araújo 2002; Mota and Castro 2004; Waluszewski 2004; Baraldi 2006; Baraldi et al. 2006; Baraldi and Stromsten 2006; Håkansson et al. 2006; Lundberg 2008; Prenkert et al. 2010; Nicholson et al. 2013b; Prenkert 2013).

IMP researchers have extended the network vision to the spatial context, focusing their investigations on "regional strategic networks" (Andresen et al. 2008; EklinderFrick et al. 2012). In general, they tend to use the conceptual background of industrial networks to the territorial networks, aiming at both understanding the process underlying regional dynamics as well as providing guide-lines on the promotion of regional development (Nicholson et al. 2013a).

In this line, regions are considered as business actors "in control of some certain abilities and resources the most important being the organizing capability" (Prenkert 2013: 22). The concept of place is considered as something "that affects not only the individual company, but also the way the individual company interacts with other companies" (Håkansson et al. 2006: 231). It is also considered that the interaction between organizations creates the place. We take it for granted that regions have different types of atmospheres and resources that constrain the business activity, although many of these conditions are of an intangible nature (Johnston and Araújo 2002). The essence of social and institutional relationships which evolve in a regional context is unique, inimitable and it affects the potential and attractiveness of the region in which they develop. In fact, the route of regional development is conditioned by the organizations it houses and by their relational pattern (Mota and Castro 2004; Baraldi 2006).

Regional dynamics are influenced by local connections and by connections with actors outside its region. Each organization can be seen as a combination of resources of a regional constellation (Håkansson et al. 2006). This constellation is dynamic and will be improved by the attraction of new firms or by the enrichment and enhancement of the existing resources, which may happen through their connection with other firms. Regions can be also considered as business actors "in control of some certain abilities and resources the most important being the organizing capability" (Prenkert 2013: 22). 


\section{Research questions and framework for analysis}

The literature reviewed has as a common underlying theme which is the principle of recognizing a bidirectional influence between business activities and regional dynamics. It also unanimously recognises the regional and business specificities and, using the interactive approach, it is possible to detail the factors that influence the strategic performance of the firms. However, there has not yet been sufficient explanation of how this mutual influence happens. This is why our research questions have been drawn up in the following way:

We would like to see a clarification of the role of the firm's strategic action for the dynamics of the region and assess the importance of the specificities of the business actor in this process. Similarly, there is a need to clarify the importance of the relational pattern to the regional dynamics and the role of regional characteristics for potentiating the effects of these relationships. Therefore the first research question is:

\section{Research Question 1}

How does the firm's strategic action influence the structure and dynamics of the region where it is located?

The lack of knowledge about the influence of regional characteristics on firms was another common denominator found in the literature reviewed. Thus, there is a need to clarify this dependence and the way it operates on firms. In other words, how do the regional characteristics influence the firm? This idea is operationalised in the following question:

\section{Research Question 2}

How do the regional structure and dynamics influence the firm's strategic action?

The answer to these questions was sought with the aid of an analysis model developed through the articulation of the theoretical approaches studied (Fig. 1). The model was developed according to two main concerns: to represent the process of bidirectional influence between the firms and the regions and to serve as an instrument to support empirical research in the field. Each of these dimensions will provide useful guidance on the information to collect and analyze (Table 1).

Through recognizing the specificity of the business actors (Ford and Håkansson 2006b; Huemer et al. 2004) and their importance for regional dynamics (Schoenberger 1999; Taylor and Asheim 2001; Bathelt and Glückler 2003; Martin and Sunley 2003; Yeung 2005a; Giuliani 2007), the focal firm was placed as the origin of the model. Making use of the knowledge arising from the interaction approach, emphasis has been put on the firm's strategic action, making it depend on its theory, position and resources.

Theories, network positions and different resources lead firms to specific strategic actions which decisively influence the choice of counterparties with whom they relate and the way this relation evolves. The configuration of relations within a company with a region also depends on regional characteristics. These characteristics are built on several factors such as the context, the path dependence, various contingencies and the local absorption capacity towards the firm's performance (Amin 1999; Lee 2002; Bathelt and Glückler 2003; Waluszewski 2004; Baraldi et al. 2006; Bathelt 2006; Maskell and Malmberg 2007). 


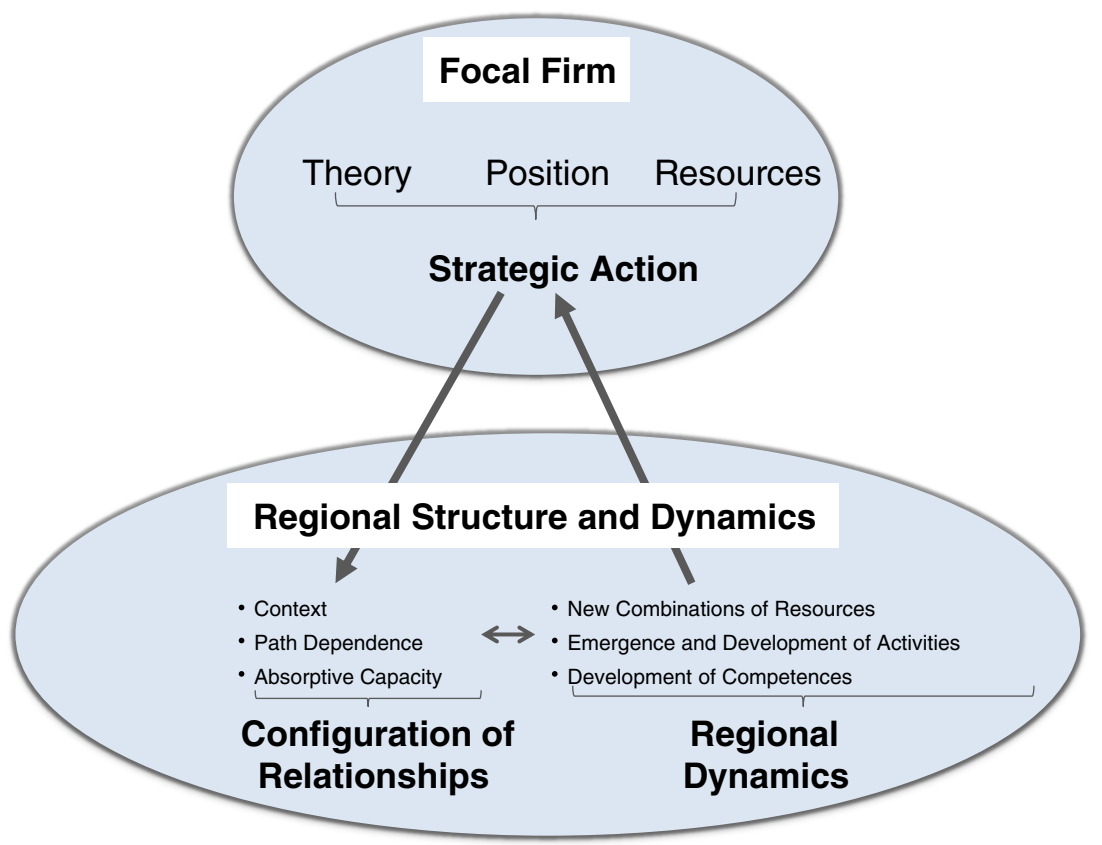

Fig. 1 Framework for analysis

Each organization can be viewed as a particular combination of resources in a constellation that exists in a given region (Håkansson et al. 2006). This constellation is both dynamic and it is changed through interaction (Waluszewski et al. 2008). As such, depending on the interaction of the focal firm's network with the region, which takes place through the firms and established organizations, a number of factors that have an impact on the regional dynamics may occur. This is the case of the emergence of new connections among local firms or the combination of existing resources, the

Table 1 Dimensions of analysis

\begin{tabular}{|c|c|c|c|}
\hline \multicolumn{2}{|c|}{ Dimensions } & \multicolumn{2}{|c|}{ Sub-dimensions } \\
\hline \multirow[t]{3}{*}{ A } & Strategic Action & A1 & Network Theory \\
\hline & & $\mathrm{A} 2$ & Position \\
\hline & & A3 & Resources \\
\hline \multirow[t]{3}{*}{$\mathrm{B}$} & Configuration of Relationships & B1 & Context \\
\hline & & $\mathrm{B} 2$ & Path Dependence \\
\hline & & B3 & Absorptive Capacity \\
\hline \multirow[t]{4}{*}{$\mathrm{C}$} & Regional Structure and Dynamics & $\mathrm{C} 1$ & New Combinations of Resources \\
\hline & & $\mathrm{C} 2$ & Emergence and Valorisation of Activities \\
\hline & & $\mathrm{C} 3$ & Development of Competences \\
\hline & & $\mathrm{C} 4$ & Influence on the Focal Firm \\
\hline
\end{tabular}


emergence of new activities and enhancement of pre-existing activities as well as the development of competences (Håkansson and Waluszewski 2002; Wilkinson and Young 2002; Ritter et al. 2004; Håkansson et al. 2006; Johnston et al. 2006).

The interaction produced by the business organisations is one of the main factors influencing the network theory. It can be said that to a large extent firms are the result of their relations (Håkansson and Ford 2002; Snehota 2004). The change in the structure and dynamics of the region caused by changes in the pattern of relations among the established firms may therefore lead to an effect on the theory of the focal firm and to a readjustment of their initial strategy. This change will transform their entire network of relations and consequently all its relations within the region. This is because network theories do not only affect the strategic performance of the actors which formulate them, but may be transmitted to other actors and eventually influence their action (Brito 2001).

\section{Methodology}

More than quantifying variables, the aim of this study is to clarify the bidirectional influence between business action and regional dynamics. This happens within specific realities and this is the reason why it is important to collect several details about the research context. Hence a qualitative methodology was considered the most appropriate to guide this study. Indeed, the relational perspective is especially prone to the use of flexible analysis methodologies which fit the connectivity of the data to be collected (Dubois and Araújo 2004). This flexibility suited to the relational approaches is quite evident in the qualitative methods which also generate deep knowledge of the phenomenon to be studied (Carson et al. 2001).

Among all the qualitative methodologies we decided upon a case study because of its ability to capture the dynamics of the phenomenon (Eisenhardt 1989). One of the advantages of case studies is the use of multiple sources of information (Eisenhardt and Graebner 2007). The process of data collection was therefore based on several sources: interviews, internal documents of the firms, local development plans, regional statistics, catalogues, newspapers and internet sites. Of the multiple sources of information used interviews are clearly predominant, thus revealing the most appropriate means to monitor the interactions and the dynamic processes which underlie the process of bidirectional influence. As stated by Ackroyd and Hughes (1992) with the use of verbal reports offered by the interviewees the researcher has access to an almost infinite variety of information that would be impossible to obtain through other means.

The case of influence studied for this purpose was the relationship between the firm Aquapura and the Portuguese Douro region. Between May and October 2009, 12 individual semi-structured interviews were carried out with several personalities and after a preliminary exploratory analysis they were categorized as relevant to assess this process of mutual influence (Table 2).

During the interviews, which lasted between one hour and two hours thirty minutes, resulting in about $16 \mathrm{~h}$ of recording, a script was followed. It was mainly designed to clarify the identified dimensions of the analysis (Table 1). The interviews were transcribed for later analysis. We then also decided to include them in the next section, where an analysis of the case is made, namely through excerpts of the interviews. In 
Table 2 Interviews

\begin{tabular}{|c|c|c|c|}
\hline Interviewee & Function & Interviews & $\begin{array}{l}\text { Interviewee } \\
\text { Code }\end{array}$ \\
\hline Sofia Brandão & Marketing Director of Aquapura & $\begin{array}{l}1 \times 2 h+\text { visit to the } \\
\text { enterprise }\end{array}$ & AQ-SB \\
\hline Cecília Veloso & Front Office Manager of Aquapura & $1 \times 1 \mathrm{~h}$ & AQ-CV \\
\hline Philippe Bossert & Chef of Aquapura & $1 \times 1 \mathrm{~h}$ & AQ-PB \\
\hline Joana Van Zeller & Public Relations of Aquapura & $\begin{array}{l}1 \times 1 \mathrm{~h} 45 \mathrm{~m}+\text { visit to } \\
\text { the enterprise }\end{array}$ & AQ-JV \\
\hline Rui Paula & Chef and owner of Restaurant DOC & $1 \times 2 h$ & AQ-RP \\
\hline Pedro Cardoso & Director of Aris Douro & $1 \times 1 \mathrm{~h}$ & AQ-PC \\
\hline Edgar Gouveia & Owner of Restaurant Castas e Pratos & $1 \times 1 \mathrm{~h}$ & AQ-EG \\
\hline Teresa Serpa Pimentel & Owner of Quinta da Pacheca & $\begin{array}{l}1 \times 2 \mathrm{~h} 30 \mathrm{~m}+\text { visit } \\
\text { to the farm }\end{array}$ & AQ-TP \\
\hline José Serpa Pimentel & Director of Quinta da Pacheca & $1 \times 1 \mathrm{~h}$ & AQ-JP \\
\hline Marta Sá Lemos & Executive Director of ADETURN & $1 \times 2 h$ & AQ-ML \\
\hline Ricardo Magalhães & $\begin{array}{l}\text { Project Manager of Estrutura de Missão } \\
\text { do Douro }\end{array}$ & $1 \times 1 \mathrm{~h}$ & AQ-RM \\
\hline \multirow[t]{4}{*}{ Nuno Fazenda } & Director of CCDR-N & $1 \times 2 h$ & AQ-NF \\
\hline & Total of Interviewees & 12 & \\
\hline & Total of Interviews & 12 & \\
\hline & Total hours of interview & $16 \mathrm{~h} 15 \mathrm{~m}$ & \\
\hline
\end{tabular}

this way it is possible to understand the perspectives and direct awareness of the interviewees through their own words, which obviously enriches the whole analysis.

\section{The case: Aquapura vs. Douro region}

Besides demonstrating the bilateral influence process between the firm and the region, the model described in Section 3 works as a framework for the empirical analysis. Thus, after a general overview of the case studied, this is analysed according to each of the dimensions included in the model.

\subsection{General overview}

Aquapura is a tourist resort located in the Douro valley in northern Portugal (Fig. 2). It was founded in 2007 by a group of managers and investors who aimed at offering an exclusive experience for tourists based on top quality facilities and a wide range of services.

Aquapura Douro Valley has fifty rooms and twenty-one villas. A large SPA (with 2200 square meters) is a central element of the resort built around a 19th century manor house of Quinta de Vale Abraão, one of the most distinctive Douro estates. This five star hotel employs 100 people, having also created 250 new indirect jobs. On average guests stay in this hotel 2.2 nights while in the Douro valley they stay only 1.7 nights. 


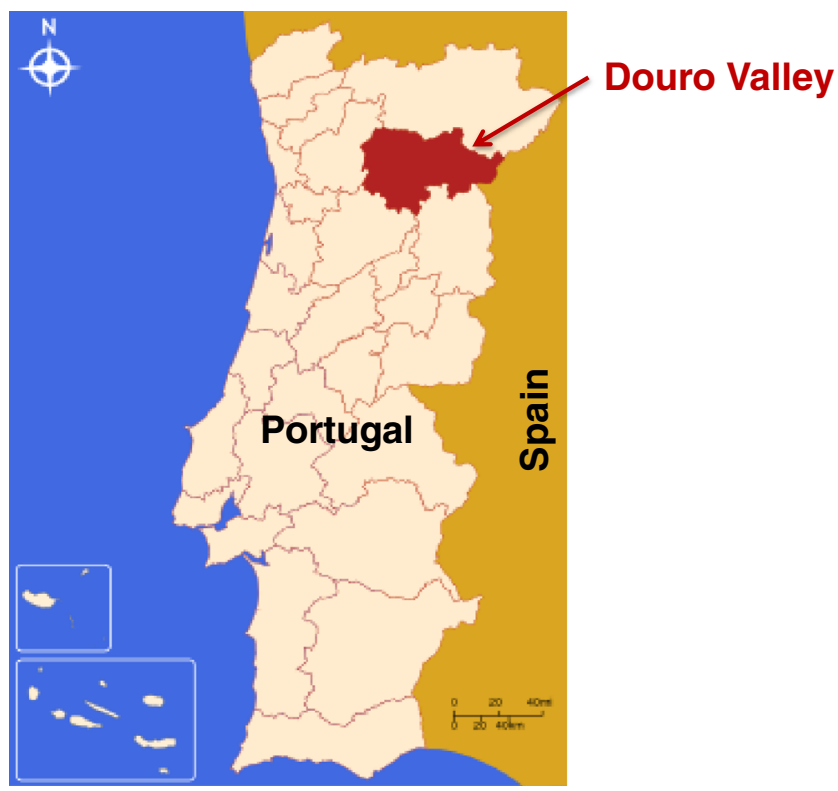

Fig. 2 The Douro Valley

Due to its quality, Aquapura has received a number of important awards. In 2009 it was included in the Tatler Guide of top hotels in the world (only another Portuguese hotel was included in the guide), and it became a member of the Small Luxury Hotels of the world. In 2010 the Taschen Spa Guide considered Aquapura Spa as one of the best spas in the world (it was the only Portuguese spa included in the guide). In 2011 the readers of Condé Nast Traveller voted it as the sixth best European hotel. And in 2013 it won the TripAdvisor Certificate of Excellence.

The Douro valley is located in the North of Portugal, one hundred kilometres away from Porto. It is the first demarcated wine region in the world, with boundaries administratively established in 1756 . It has an area of 250.000 ha, being approximately 30.000 ha occupied by vineyards. In 2001 it was classified by UNESCO as World Heritage Site under the caption of "a living evolutive cultural landscape". The vineyards, planted in slopes that form a unique landscape alongside the river Douro, are one of its main distinctive attractions. It is in this region that the famous Port wine is produced. More than $80 \%$ of Port wine is shipped, accounting for almost one third of Portuguese wine exportations.

For these reasons, the valley is considered a touristic destination with high potential. This is officially recognized by the Portuguese government who classified it as a priority area for tourism.

\subsection{Case analysis}

After this overview of both the company and the territory where it is located, the following sections encompass an analysis of this case on the basis of the dimensions presented in Table 1: A - strategic action; B - configuration of relations; and C regional structure and dynamics. 


\subsubsection{Dimension A: strategic action}

- Sub-dimension A1: Aquapura Network Theory

Aquapura is not positioned in the so-called mass tourist destinations. This operational strategy does therefore achieve a clear differentiation from what is being offered, but requires a significant communication effort. The Douro destination, in the initial phase of its tourism development process actually favours the Aquapura policy of only locating hotels in non-overcrowded destinations, which are outside the typical commercial circuits.

Another guiding principle of the Aquapura concept is the belief in interaction with diverse actors in order to provide an excellent service. The organization considers the regional actors fundamental to the achievement of several goals, including their most important one: to be one of the best hotels in the world. Aquapura understands their network of relations as fundamental to meet two main goals: to improve the awareness of the brand and of the destination and to broaden its range of services in the region.

While most of the tourist actors in the Douro valley base their operation exclusively on their own resources and competences, Aquapura managers perceive that its strategy should take into account the role played by local actors. This understanding reflects a strong network approach. Aquapura also reveals no problem in promoting other local actors. Indeed, it organizes tours that include other farms and restaurants in the area. This vision, reflecting the importance given to local actors with complementary characteristics, is described by Marta Sá Lemos as follows:

"They (Aquapura) have the strong perception that without other companies, without restaurants, even without other hotels, it is impossible to promote the destination. You need to have taken a big step in terms of mentality to have this understanding. When we support joint actions with Aquapura, for example organizing a press visit of specialized English or American journalists, they (Aquapura) don't care if they visit other hotels" (AQ:ML).

\section{- Sub-dimension A2: Strategic Position}

Aquapura was the first five-star hotel to be created in the Douro region. The refurbishing of the emblematic Quinta de Vale Abraão manor house required an investment of 30 million Euros. This enterprise is the largest private tourism investment in the Douro so far and has recently seen its merit recognized by the Turismo de Portugal Awards.

Due to the luxury it involves, Aquapura is seen as an innovative concept and this has resulted in it becoming a reference actor in the region. Another consequence is the ability to influence the local tourism network.

Because Aquapura is located in a destination which has only now begun to develop, other firms look at it as an example to follow. Due to its position as a dominant actor Aquapura has become an influence for those firms which aim at a higher positioning. In point of fact some of the already existing new tourism spaces of the region have taken inspiration from some of the concepts created by Aquapura. 
- Sub-dimension A3: Resources

The Aquapura project is based on highly professionalized management, usually not a feature of the independent hotel projects. Indeed, among the main resources of the hotel some rather cosmopolitan resources exist and they not only have a clear understanding of the tourism activity but also possess a broad network of contacts. These human resources allow them to have access to the best international practices developed in tourism as well as to gain notability among the network of relations. One of the most significant features of Aquapura is its ability to communicate abroad through delegates in several markets which carry out their action in order to positively influence their future.

This ability to generate awareness is regarded by some respondents as a distinctive characteristic of Aquapura. Marta Sá Lemos declares:

"It is difficult to find a hotel following a marketing network approach as Aquapura." (AQ:ML)

Due to this strategic approach, journalists of some of the most famous international magazines have visited the Douro valley, as Teresa Serpa Pimentel puts it:

"Aquapura has done what the regional tourism authorities have never done because these don't have capacity for it." (AQ:TP)

\subsubsection{Dimension B: configuration of relationships}

- Sub-dimension B1: Context - The Douro Region

Several documents as well as legislation consider this region a place with a great vocation for tourism. It is also the home of the best-known Portuguese product abroad (Port wine). However, the Douro is a region with one of the lowest purchasing power indexes (70.8 points in the index of the INE in a 100 scale) of Portugal and Europe. Twelve of the nineteen municipalities of this region have an even lower index of purchasing power which is below 56 points (INE 2011).

The development of tourism in the Douro valley is still feeble. The region is responsible for only one per cent of Portugal's accommodation capacity. In 2005 it had thirty-six hotels with a total of two thousand three hundred and seventeen beds (Magalhães et al. 2008). The average permanence rate of tourists in the Douro region is of 1.7 nights while the global rate in Portugal is 3.1 nights. This shows the inability of the Douro region to generate attractions that justify the permanence of tourists for longer periods of time.

Three municipalities of the region (Vila Real, Régua and Lamego) account for sixtyeight per cent of overnight stays. In addition to the fact that they are the main urban centres, the concentration of tourism in these municipalities is also justified by the difficulty of mobility within the region. With the exception of these cities, travelling from one place to another may be a tough task because of winding roads which contributes to the concentration of tourists in the main urban axis. For instance, the 
journey by car from the airport of Porto to Vila Real, the district capital of the Douro region, takes approximately one hour. However, the hundred and ninety kilometres that separate Aquapura from Miranda do Douro (the furthest northern location of the region) takes more than three hours.

\section{- Sub-dimension B2: Path Dependence}

The typical matrix of accommodation of the Douro is the estate house. These properties were initially merely the country house of the Douro wine producers. However, they were gradually transformed into tourist accommodation units and most of them opened to tourist activities such as wine tasting events or meals. Despite this, most of the estates owners still do not possess any training in the area of tourism, which would allow them to offer a quality product and understand the way this industry (so different from the wine industry) works.

It is interesting to see how these actors are quite attached to the wine industry. Wine production is the result of arduous tasks, which are performed hidden inside the farms or estates. Tourism requires sensitivity, openness and understanding of the visitors' motivations and needs. The number of existing tourists does not yet allow farms and small hotels in the region to have the excellent human resources needed to position the destination at the highest level.

It was only two years ago that a regional tourism agency, Turismo do Douro (Douro Tourism), was created in the valley. Until then, the destination was divided into three tourism regions, run by agencies that operated independently with little or no synergies among them. For this reason, the region did not manage to create a brand with a global awareness and an image that clearly adds value to the destination.

A clear absence of an understanding of tourism on the part of a significant number of actors with responsibility in the tourism industry in the region seems obvious. There is no tourist offer related with the wine in the main towns. In most of the restaurants there are no wine lists, the cultural legacy is partially abandoned, the internal mobility is poor and the municipal action barely combines efforts of performance. Because of these significant limitations with regard to the creation of value, the items of Governance, Marketing and Sales and Tourism Circuits were classified as having a poor performance by the World Centre of Excellence for Destinations (CCDR-N 2008) in a recent assessment of the Douro.

\section{- Sub-dimension B3: Absorptive Capacity}

Aquapura has shown great sensitivity in searching for local partners to complement their offer. However, the number of local partners consistent with the operating principles of Aquapura is reduced, which limited its regional connections. Because of the status of tourism initiation in which the destination is, it is necessary for tourism actors to offer activities which may complement the Aquapura offer. These actors have still not appeared, even after this stimulus. Sofia Brandão explains this:

"We are in a wine region with a rich cuisine and we do not have any gourmet stores, when, in fact, it would be easy to send our clients to restaurants, museums and farms but when people ask where they can buy local products there is 
nowhere we can send them. That is one thing that we cannot overcome, there are no good stores to purchase products from the region." (AQ:SB)

Existing relations are established with actors who position themselves at the same level of this project and who are able to complement their service, thus generating a tourism product offer to the customer with greater authenticity. Also due to the already mentioned difficulty of internal mobility, because regional roads are poor, causing short distances to take a long time, the selected local partners were situated preferentially near the hotel.

The lack of sensitivity in terms of tourism and the inability to take advantage of the region's resources do not only reflect on private agents and their lack of initiative. The regional administration does not take enough advantage of the promotion made by Aquapura and of the potential resources which exist in the region. There are no relevant events or conferences, the internal signalling of the destination does not exist and, in fact, there is a lack of knowledge of the population with regard to the reality that is intended for the Douro. Most municipal performance is still focused on small works and town sized events with little relevance to the destination as a whole.

In the case of Aquapura, a tourism actor operating on a higher level of the value chain, the absorption of knowledge by the region is limited (Fig. 3). A significant number of the actors of the region cannot take advantage of the existence of a pole of attraction such as Aquapura, which has proven to give visibility and attract more wealthy tourists.

\subsubsection{Dimension C: regional structure and dynamics}

Although there is no coordinated action on the part of regional entities in order to enhance the effects of Aquapura's presence, several local partnerships were developed which combine features of excellence, allowing greater visibility and new activities. The project influenced some local actors positively and contributed to the enrichment of core competences for tourism of human resources in the region.

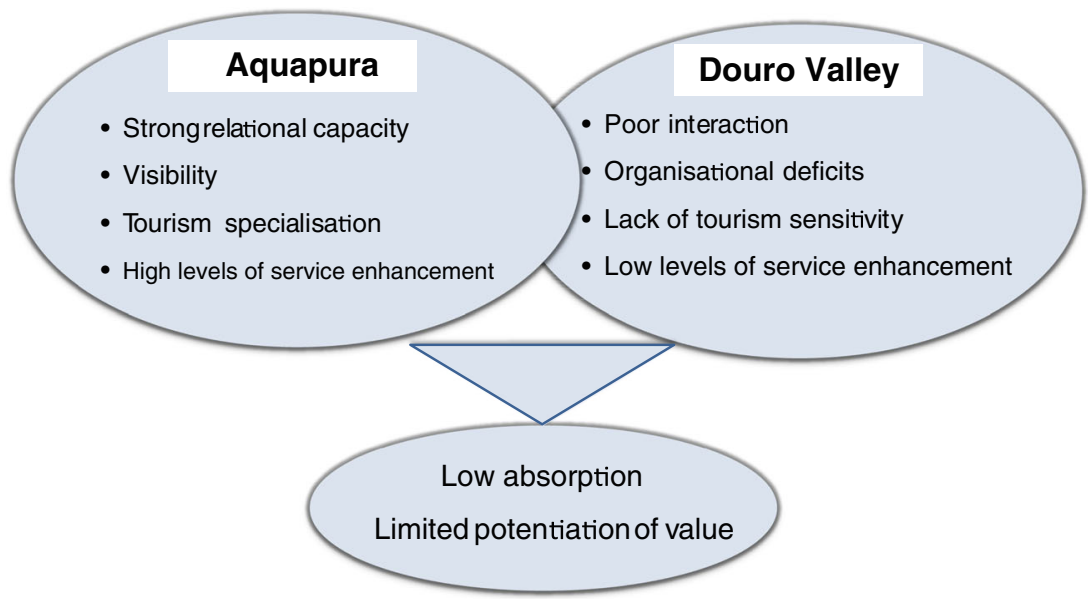

Fig. 3 Regional absorption vis-à-vis Aquapura's presence 
- Sub-dimension C1: New Combinations of Resources

Aquapura has connected the region with specialized operators in luxury markets of wine tourism, making it more visible at international level and a destination highly recommended by travel agents. Thanks to the presence of Aquapura in the region it was possible to combine an excellent tourism resource with excellent wine resources. This resulted in positive developments for the region.

One of the success stories of this resource joint-venture was materialized through the Grand Jury Européen in Portugal. This is a jury with about forty major international wine experts from fourteen countries in Europe and the United States, several oenologists, national and international journalists, world champion sommeliers and producers. They evaluate the wines of a given region and for a whole weekend gathered at Aquapura, where they assessed the Douro wines. According to Sofia Brandão:

"These people would never have come here if there had not been for a five-star hotel and if there was not our promotional activity." (AQ:SB)

- Sub-dimension C2: Emergence and Valorisation of Activities

Aquapura's presence, with the customers profile associated to it, stimulated the emergence of activities to support tourism in the region. The transfer service in luxury cars was one of these new activities.

Due to the demands of Aquapura a set of individual services offered to every tourist sent by the Hotel to the partner farms also appeared. This clearly provides some added value. The action and influence of Aquapura also enabled the opening of some farms to wine tourism, thus giving the Douro new tourism resources.

The emergence of Aquapura also led to a boost in luxury restaurant projects. The percentage of customers (around 30\%) sent by Aquapura to partner restaurants is very significant. According to Joana Van Zeller:

"After we (Aquapura) opened there was a tidal wave. Three more premium restaurants were created, where there was only one. That is, we had a growth of $300 \%$ of restaurants in a year.” (AQ:JV)

\section{- Sub-dimension C3: Development of Competences}

Aquapura has established a partnership with the Hotel Management School of Lamego (a city located in the Douro) and the training of its human resources has been done there. Subsequently employees trained at this school were hired. Besides this, the director of accommodation at Aquapura also gives training to students of the school, which raises the standards of that institution.

Some local restaurants have gained competences through the hiring of Aquapura's former employees. This is the case of the "Castas e Pratos" restaurant and the "Douro in", where the head waiter and the chef are both former employees of Aquapura. 
- Sub-dimension C4: Influence on the Focal Firm

The characteristics of the Douro as a developing tourist destination have had effects on the activities foreseen by Aquapura. The number of tourists that Aquapura hoped to attract fell short of expectations, which motivated a downward correction of the prices, a situation which has negatively affected the image of the project.

Several activities necessary to complement the offer of the Aquapura have not emerged, because of the absence of a critical number of tourists, and others that were blocked by the existence of some organizational barriers. In fact, several organizational obstacles related to public resources are preventing the emergence of potential additional activities at Aquapura. Despite being one of the great resources of the region, the Douro River is not signalled at night, which, as stated by Teresa Serpa Pimentel, makes its nocturnal navigation impossible:

"There would be many potential businesses such as small boats that would pick up the tourists at the hotel and take them to a restaurant etc. But the river is not signalled and at night you cannot navigate after 5:30 pm.” (AQ:TP)

Train excursions in the Douro, one of the most popular activities for tourists, are also hindered by administrative impediments and divergence of interests. As can be seen from the words of Joana Van Zeller this situation penalizes the service which is offered to the Aquapura client:

"Our clients seek activities which are related to the train, but there are only two trains up and two down, and they necessarily have to have lunch there. For example, to go to the Vesúvio wine estate they can go in the morning, do a tasting and they have lunch there, but then they only have a train back at 5:30 pm." (AQ:JV)

Although they are not the responsibility of Aquapura, these limitations contribute to a weaker image of the destination where the project is located.

The intention to attract a target audience abroad was hampered by the poor visibility and by a low public investment in this region. So, Aquapura's communication policy, which was strongly geared towards attracting foreign tourists, had to be reoriented in order to give greater importance to national tourists.

The fact that the region is limited in terms of road infrastructures makes the Aquapura's proposals more concentrated from the geographic point of view. In this way it is not possible to take advantage of all the tourism resources in the region. For example the Foz Côa engravings, classified as world heritage, are two hours away by car and tourists have to use uncomfortable roads.

As mentioned by Sofia Brandão, these characteristics of the destination led to an unavoidable adaptation of Aquapura to what is offered by the region:

"We have to adapt ourselves to what exist here. If the region offers us something, we often have to adopt it. (...) In a flexible way we have adapted a few things because at the end of the day we have to fulfil the expectations of customers." (AQ:SB) 


\section{Conclusions}

Regional environments affect the activity of firms, conditioning and assigning them characteristics specific to that context. Depending on the features of the actors involved in this process, interaction will have greater or lesser ability to potentiate the structure and dynamics of the region.

The most important contributions of this paper derive from the two research questions raised in the third section. Firstly, the study reveals that the presence of Aquapura gave rise to the emergence of a number of local partnerships. These combined high quality resources, increased the awareness of the region and created the conditions for the development of new activities in the Douro valley. In this regard, we can say that the project had a positive impact on other local actors, contributing to the emergence of new tourism skills which, in its turn, increased the attractiveness of the region as a whole.

Secondly, on the other hand the study shows that the structure and dynamics of the Douro valley determined to some extent Aquapura's strategic action inasmuch as they limited the offering of the company when compared to the initial expectations of the project. In fact, having a strategy based on the service extension, local actors compatible with such a strategy were not only very limited in number but also very much focused on wine. This narrowed the network of relationships Aquapura was able to create involving local actors. Furthermore, the low international awareness of the region required an intensive international activity of promotion conducted by the company. This explains why Aquapura started devoting more attention to Portuguese tourists since these already knew the region and did not require so much communication efforts. Finally, the lack of qualified human resources in the region trigged a close involvement of Aquapura with a local tourism school in order to develop new training programs directed to its workers.

We can thus conclude that because of the process of interaction with the focal firm, local actors are likely to condition the possibilities of interaction or ways to act in the market, develop new activities on the basis of innovative ways to combine their resources, connect with other actors of the focal firm's network and create new competences. Regarding regions as constellations of resources which highlight firms, the occurrence of these effects is likely to increase their capacity to attract new tourists. On the other hand, the inability of local actors to interact with the focal firm can limit its impact on the dynamics of the territory as a whole.

The managerial implications are mainly directed to those who can influence public policies of regional development. No matter what one says, wants and thinks, a region will never become a destination of excellence if there are no tourism actors which excel. And the tourism actors of excellence are not only those who by their physical infrastructures provide the region with the best accommodation capacity. There is also a need for actors who, through their relational capabilities, are able to promote themselves altogether, integrate offerings and enhance the existing resources.

The main limitations of this paper are, at the same time, opportunities for further research. The model presented is valid for all types of business actors. However, tourism firms have a number of idiosyncrasies when compared to firms of other sectors. This means that the study must be regarded as a starting point for the development of an appropriate theory which takes into account these particularities. Literature recognizes 
the effect of the influences which have occurred in several scales thus manifesting themselves in a particular region. However, the model only reflects those influences indirectly, through the conditioning elements of the strategic action. There is another research opportunity deriving from the need for clarification of the influence of firms operating outside the region under analysis.

\section{References}

Ackroyd, S., \& Hughes, J. (1992). Data collection in context. London: Longman.

Amin, A. (1999). An institutionalist perspective on regional economic development. International Journal of Urban and Regional Research, 23, 365-378.

Amin, A. (2004). Regions unbound: towards a new politics of place. Geografiska Annaler, 86(1), 33-44.

Anderson, J., Håkansson, H., \& Johanson, J. (1994). Dyadic business relationships within a business network context. Journal of Marketing, 58(4), 1-15.

Andresen, E., Lundberg, H., \& Roxenhall, T. (2008). Regional Strategic Networks - The Impact of Initial Conditions and Activities on Outcomes. Paper presented at the 24th IMP Conference, Uppsala, Sweden.

Ateljevic, J., \& Doorne, S. (2004). Diseconomies of scale: a study of development constraints in small tourism firms in central New Zealand. Tourism and Hospitality Research, 5(1), 5-24.

Baraldi, E. (2006). The places of Ikea: Using space in handling resource networks. In E. Baraldi, F. Hjalmar, \& A. Houltz (Eds.), Taking place: The spatial contexts of science, technology and business (pp. 297-320). Sagamore Beach: Science History Publications/USA.

Baraldi, E., \& Stromsten, T. (2006). Combining scientific knowledge and venture capital across places and networks of resources. In A. Houltz, F. Hjalmar, \& E. Baraldi (Eds.), Taking place: The spatial contexts of science, technology and business (pp. 247-273). Sagamore Beach: Science History Publications/USA.

Baraldi, E., Hjalmar, F., \& Houltz, A. (2006). Taking place: The spatial contexts of science, technology and business. Sagamore Beach: Science History Publications/USA.

Bathelt, H. (2006). Geographies of production: growth regimes in spatial perspective 3 - toward a relational view of economic action and policy. Progress in Human Geography, 30(2), 223-236.

Bathelt, H., \& Glückler, J. (2003). Toward a relational economic geography. Journal of Economic Geography, 3, 117-144.

Bathelt, H., \& Glückler, J. (2011). The relational economy: Geographies of knowing and learning. Oxford: Oxford University Press.

Bathelt, H., \& Glückler, J. (2013). Institutional change in economic geography. Progress in Human Geography, published online.

Bathelt, H., \& Li, P. (2014). Evolutionary economic geography and relational geography. In M. Fischer \& P. Nijkamp (Eds.), Handbook of regional science. Berlin: Springer.

Boggs, J., \& Rantisi, N. (2003). The 'relational turn' in economic geography. Journal of Economic Geography, 3, 109-116.

Boschma, R., \& Martin, R. (2010). The Handbook of Evolutionary Economic Geography: Edward Elgar.

Boyle, D. (2004). Authenticity: Brands, fakes, spin and the lust for real life. London: Harper Perennial.

Brito, C. (2001). Towards an institutional theory of the dynamics of industrial networks. Journal of Business and Industrial Marketing, 16(3), 150-166.

Carson, D., Gilmore, A., Perry, C., \& Gronhaug, K. (2001). Qualitative marketing research. Thousand Oaks: Sage.

CCDR-N (2008). Vale do Douro, Norte de Portugal - Relatório Executivo do Sistema de Medição de Excelência dos Destinos. Porto: Comissão de Coordenação e Desenvolvimento Regional do Norte.

Cohen, W., \& Levinthal, D. (1989). Innovation and learning: the two faces of R\&D. The Economic Journal, 99, 569-596.

Cova, B., Mazet, F., \& Salle, R. (1996). Milieu as a pertinent unit of analysis in project marketing. International Business Review, 5(6), 647-664.

Dicken, P., \& Malmberg, A. (2001). Firms in territories: a relational perspective. Economic Geography, 77(4), 345-363.

Dicken, P., Kelly, P. F., Olds, K., \& Yeung, H. W.-C. (2001). Chains and networks, territories and scales: towards a relational framework for analysing the global economy. Global Networks, 1(2), 89-112. 
Dubois, A., \& Araújo, L. (2004). Research methods in industrial marketing studies. In H. Håkansson, D. Harrison, \& A. Waluszewski (Eds.), Rethinking marketing - developing a new understanding of markets (pp. 207-227). London: Wiley.

Eisenhardt, K. (1989). Building theories from case study research. Academy of Management Review, 14(5), $532-550$.

Eisenhardt, K., \& Graebner, M. (2007). Theory building from cases: opportunities and challenges. Academy of Management Journal, 50(1), 25-32.

Eklinder-Frick, J., Eriksson, L., \& Hallén, L. (2012). Effects of social capital on processes in a regional strategic network. Industrial Marketing Management, 41(5), 800-806.

Ettlinger, N. (2003). Cultural economic geography and a relational and microspace approach to trusts, rationalities, networks, and change in collaborative workplaces. Journal of Economic Geography, 3, 145-171.

Ford, D., \& Håkansson, H. (2006a). The idea of business interaction. IMP Journal, 1(1), 4-20.

Ford, D., \& Håkansson, H. (2006b). IMP - some things achieved: much more to do. European Journal of Marketing, 40(3/4), 248-258.

Giuliani, E. (2007). The selective nature of knowledge networks in clusters: evidence from the wine industry. Journal of Economic Geography, 7, 139-168.

Glückler, J. (2007). Economic geography and the evolution of networks. Journal of Economic Geography, 7 , 619-634.

Granger, R. (2013). Spatial-Relational Mapping in Socio-Institutional Perspectives of Innovation. European Planning Studies, published online.

Grängsjö, Y. (2003). Destination networking co-opetition in peripheral surroundings. International Journal of Physical Distribution and Logistics Management, 33(5), 427-448.

Håkansson, H. (1982). International marketing and purchasing of industrial goods. Chichester: Wiley.

Håkansson, H., \& Ford, D. (2002). How should companies interact in business networks? Journal of Business Research, 55(2), 133-139.

Håkansson, H., \& Waluszewski, A. (2002). Managing technological development - IKEA, the environment and technology. London: Routledge.

Håkansson, H., Tunisini, A., \& Waluszewski, A. (2006). Place as a resource in business networks. In A. Houltz, F. Hjalmar, \& E. Baraldi (Eds.), Taking place: The spatial contexts of science, technology and business (pp. 223-246). Sagamore Beach: Science History Publications/USA.

Hjalager, A.-M. (2000). Tourism Destinations and the Concept of Industrial Districts. Paper presented at the 9th Nordic Tourism Research Conference, Bornholm, Denmark.

Holmen, E., \& Pedersen, A.-C. (2003). Strategizing through analyzing and influencing the network horizon. Industrial Marketing Management, 32, 409-418.

Huemer, L., Becerra, M., \& Lunnan, R. (2004). Organizational identity and network identification: relating within and beyond imaginary boundaries. Scandinavian Journal of Management, 20(1-2), 53-73.

INE. (2011). Estudo sobre o Poder de Compra Concelhio 2009. Lisboa: Instituto Nacional de Estatística.

Jamal, T., \& Getz, D. (1995). Collaboration theory and community tourism planning. Annals of Tourism Research, 22(1), 186-204.

Johanson, J., \& Mattsson, L. (1992). Network positions and strategic actions - an analytical framework. In B. Axelsson \& G. Easton (Eds.), Industrial networks: A new view of reality (pp. 205-217). London: Routledge.

Johnston, B., \& Araújo, L. (2002). The Effects of Spatial Proximity on Inter-Organisational Relationships. Paper presented at the 18th IMP Annual Conference.

Johnston, W., Peters, L., \& Gassenheimer, J. (2006). Questions about network dynamics: characteristics, structures, and interactions. Journal of Business Research, 59, 945-954.

Koch, C., Jørgensen, C., \& Mathiasen, J. (2013). Strategic sourcing development - emerging resource combination and knowledge interaction. The IMP Journal, 7(1), 12-23.

Lee, R. (2002). 'Nice maps, shame about the theory'? Thinking geographically about the economic. Progress in Human Geography, 26(3), 333-355.

Lundberg, H. (2008). Geographical Proximity Effects and Regional Strategic Networks. Doctoral Thesis, Department of Business Studies, Uppsala University.

Magalhães, R., Fazenda, N., Alegria, E., Gomes, J., \& Costa, V. (2008). Plano Desenvolvimento Turístico do Vale do Douro 2007-2013: Estrutura de Missão do Douro.

Martin, R., \& Sunley, P. (2003). Deconstructing clusters: chaotic concept or policy panacea? Journal of Economic Geography, 3, 5-35.

Maskell, P., \& Malmberg, A. (2007). Myopia, knowledge development and cluster evolution. Journal of Economic Geography, 7, 603-618. 
Mattsson, L.-G. (2003). Reorganisation of distribution in globalisation of markets: the dynamic context of supply chain management supply. Chain Management: An International Journal, 8(5), 416-426.

McKercher, B. (1993). The unrecognized threat to tourism: can tourism survive "sustainability"? Tourism Management, 14(2), 131-136.

Milne, S., \& Ateljevic, I. (2001). Tourism, economic development and the global-local nexus: theory embracing complexity. Tourism Geographies, 3(4), 369-393.

Mota, J., \& Castro, L. (2004). Industrial agglomerations as localised networks: the case of the Portuguese injection mould industry. Environment and Planning A, 36, 263-278.

Murphy, P., Pritchard, M., \& Smith, B. (2000). The destination product and its impact on traveller perceptions. Tourism Management, 21(1), 43-52.

Nicholson, J., Brennan, R., \& Tsagdis, D. (2013a). Common Territory? Comparing the IMP Approach with Economic Geography. Paper presented at the 29th IMP Conference, Atlanta, USA.

Nicholson, J., Tsagdis, D., \& Brennan, R. (2013b). The structuration of relational space: implications for firm and regional competitiveness. Industrial Marketing Management, 42(3), 372-381.

Olsen, P., Håkansson, H., \& Waluszewski, A. (2013). Value Creation and Economic Deal Structures in IMP Analysis. Paper presented at the 29th IMP Conference, Atlanta, USA.

Prenkert, F. (2013). The interactive constitution of actors in industrial networks: the case of the Norwegian City of Alesund. International Journal of Business Administration, 4(6), 10-28.

Prenkert, F., Engelseth, P., \& Raabe, H. (2010). Exploring the Networked Region. Paper presented at the 26th IMP Conference, Budapest, Hungary.

Ritter, T., Wilkinson, I., \& Johnston, W. (2004). Managing in complex business networks. Industrial Marketing Management, 33(3), 175-183.

Roseira, C., Brito, C., \& Ford, D. (2013). Network pictures and supplier management: an empirical study. Industrial Marketing Management, 42(2), 234-247.

Schoenberger, E. (1999). The firm in the region and the region in the firm. In T. Barnes \& M. Gertler (Eds.), The new industrial geography: Regions, regulation and institutions (pp. 205-224). London: Routledge.

Shaw, G., \& Williams, A. (2000). Critical issues in tourism: A geographical perspective (2nd ed.). Oxford: Blackwell Publishers.

Smeral, E. (1998). The impact of globalisation on small and medium enterprises: new challenges for tourism polices in european countries. Tourism Management, 19, 371-380.

Snehota, I. (2004). Perspectives and theories of market. In H. Håkansson, D. Harrison, \& A. Waluszewski (Eds.), Rethinking marketing: Developing a new understanding of markets (pp. 15-32). Chichester: Wiley.

Storper, M. (1997). Regional economies as relational assets. In R. Lee \& J. Wills (Eds.), Geographies of economics (pp. 248-258). London, New York, Sydney: Arnold.

Taylor, M., \& Asheim, B. (2001). The concept of the firm in economic geography. Economic Geography, 77(4), 315-328.

Turnbull, P., Ford, D., \& Cunningham, M. (1996). Interaction, relationships and networks in business markets: an evolving perspective. Journal of Business and Industrial Marketing, 11(3/4), 44-62.

Waluszewski, A. (2004). A competing or co-operating cluster or seven decades of combinatory resources? What's behind a prospering biotech valley? Scandinavian Journal of Management, 20, 125-150.

Waluszewski, A., Ford, D., Håkansson, H., Snehota, I., \& Gadde, L.-E. (2008). Analysing Business Interaction. Paper presented at the 24th IMP Conference, Uppsala, Sweden.

Wilkinson, I., \& Young, L. (2002). On cooperating: firms, relations and networks. Journal of Business Research, 55(2), 123-132.

Yeung, H. W.-C. (2005a). The firm as social networks: an organisational perspective. Growth and Change, 36(3), 307-328.

Yeung, H. W.-C. (2005b). Rethinking relational economic geography. Transactions of the Institute of British Geographers, 30, 37-51. 